\title{
PURIFICATION OF ANGIOTENSIN CONVERTING ENZYME INHIBITORY PEPTIDE DERIVED FROM KACANG GOAT MEAT PROTEIN HYDROLYSATE
}

\author{
Jamhari $^{1}$, L. M. Yusiati ${ }^{1}$, E. Suryanto, M. N. Cahyanto ${ }^{2}$, Y. Erwanto ${ }^{1}$ and M. Muguruma ${ }^{3}$ \\ ${ }^{1}$ Faculty of Animal Science, Gadjah Mada University, \\ Jl. Fauna No.3, Bulaksumur, Yogyakarta 55281 - Indonesia \\ ${ }^{2}$ Faculty of Agricultural Technology, Gadjah Mada University, \\ Jl. Flora No.1 Bulaksumur, Yogyakarta 55281 - Indonesia \\ ${ }^{3}$ Faculty of Agriculture, University of Miyazaki, \\ 1-1 Gakuen Kibanadai Nishi, Miyazaki-shi, Miyazaki, 889-2192 - Japan \\ Corresponding E-mail:jam_hari@ugm.ac.id
}

Received September 28, 2013; Accepted November 06, 2013

\begin{abstract}
ABSTRAK
Penelitian ini bertujuan untuk mengidentifikasi peptida Angiotensin Converting Enzyme (ACE) inhibitor dari hidrolisat protein daging kambing Kacang. Daging kambing Kacang bagian loin dihidrolisis dengan enzim pepsin, trypsin dan chymotrypsin. Hidrolisat protein daging kemudian diuji konsentrasi protein dan aktivitas ACE inhibitor. Peptida ACE inhibitor dipurifikasi melalui serangkaian purifikasi dengan column SEP-PAK Plus C18 Cartridge dan RP-HPLC dengan menggunakan column Cosmosil 5PE-SM, 4,6 x $250 \mathrm{~mm}$. Sekuen asam amino peptida ACE inhibitor kemudian diidentifikasi dengan menggunakan amino acids sequencer. Hasil purifikasi peptida menunjukkan bahwa sekuen asam amino peptida ACE inhibitor dari hidrolisat protein daging kambing Kacang adalah leu-thr-glu-ala-proleu-asn-pro-lys-ala-asn-arg-glu-lys. Peptida tersebut mempunyai berat molekul (BM) sebesar 1581 dan berada pada posisi residu ke-20 sampai ke-33 dari protein $\beta$-actin daging kambing (Capra hircus). Peptida tersebut mempunyai aktivitas ACE inhibitor $\left(\mathrm{IC}_{50}\right)$ sebesar $190 \mu \mathrm{g} / \mathrm{mL}$ atau $120 \mu \mathrm{M}$.
\end{abstract}

Kata Kunci: Peptida ACE Inhibitor, hidrolisat protein daging, kambing Kacang

\section{ABSTRACT}

The objective of this study was to identify the Angiotensin Converting Enzyme (ACE) inhibitory peptide derived from Kacang goat meat protein hydrolysate. Kacang goat meat loin section was hydrolyzed with pepsin, trypsin and chymotrypsin. Protein hydrolysate of Kacang goat meat was then tested the protein concentration and ACE inhibitory activity. ACE inhibitory peptide of the protein hydrolysate was purified through several steps of purification by column SEP-PAK Plus C18 Cartridge and RP-HPLC using a Cosmosil column 5PE-SM, 4.6 x $250 \mathrm{~mm}$. The sequence of amino acid of ACE inhibitory peptide was identified by amino acid sequencer. The results showed that amino acids sequence of ACE inhibitory peptide derived from protein hydrolysate of Kacang goat meat was leu-thrglu-ala-pro-leu-asn-pro-lys-ala-arg- asn-glu-lys. It had a molecular weight (MW) of 1581 and occurred at the position of $20^{\text {th }}$ to $33^{\text {rd }}$ residues of $\beta$-actin of goat meat protein (Capra hircus). The ACE inhibitory activity $\left(\mathrm{IC}_{50}\right.$ ) of the peptide was $190 \mu \mathrm{g} / \mathrm{mL}$ or $120 \mu \mathrm{M}$.

Keywords: ACE Inhibitory peptide, meat protein hydrolysate, Kacang goat

\section{INTRODUCTION}

Recent years, peptides from partial enzymatic hydrolysate of food proteins have received greater attention from food scientists than ever before since they posses many benefits. Many biological peptides, with health benefits such as antihypertensive activity, antibacterial activity, mineral-binding activity, enhancement of intestinal activity have been classified and identified from food proteins hydrolysate (Ariyoshi, 1993; Schlimme and Meisel, 1995; Steijins, 1996; Clare and Swaisgood, 2000). These peptides are inactive within the sequence of the parent protein but can be released during enzymatic digestion or food processing (Korhonen et al., 1998).

Angiotensin converting enzyme (ACE; 
peptidyl dipeptidase, EC 3.4.15.1) plays an important physiological role in blood pressure regulation and in electrolyte and fluid balance (Suetsuna 1998). This enzyme catalyzes conversion of inactive angiotensin I to potent vasoconstrictor angiotensin II by cleaving the dipeptide from the C-terminal of angiotensin I in the rennin angiotensin system, and it inactivates the vasodilator bradykinin in the kallikrein-kinin system. Angiotensin II has several central effects in leading to a further increase in blood pressure. ACE also degrades vasodilative bradykinin in blood vessels and stimulates the release of aldosterone in the adrenal cortex (Cheung et al., 1980).

Several inhibitors of ACE have been found to be effective as antihypertensive pharmaceuticals. ACE inhibitory activity in foods has also been studied (Yamamoto, 1997). ACE inhibitory peptides derived from foods, especially milk proteins (casein and whey proteins), have been reported to show antihypertensive effects in spontaneously hypertensive rats (SHR) by oral administration (Maruyama et al., 1987; Yamamoto et al., 1994; Nakamura et al., 1995; Abubakar et al., 1998; and Yamamoto et al., 1999). The antihypertensive effect of sour milk containing two ACE inhibitory peptides (Val-ProPro and Ile-Pro-Pro) derived from casein was demonstrated in SHR (Nakamura et al., 1995) and in hypertensive patients (Hata et al., 1996). Research has also been conducted to characterize the ACE-inhibitory activity derived from other foodstuffs, such as maize (Maruyama et al., 1989), fish (Seki et al., 1995), fish products (Yokoyama et al., 1992; Astawan et al., 1995), and eggs (Yoshii et al., 1999).

Arihara et al. (2001) had successfully identified and isolated peptide inhibitors for ACE from enzymatic hydrolysate of porcine skeletal muscle protein. Two potent ACE inhibitory peptides, mainly found in myosin heavy chain, have been purified from thermolysin digest. Antihypertensive activity of peptides derived from porcine myosin in spontaneously hypertension rat (SHR) was also investigated, and hydrolysate of porcine myosin and peptides showed antihypertensive activity on SHR (Nakashima et al., 2002). Purification and characterization of ACE inhibitory peptide derived from porcine troponin $\mathrm{C}$ were successfully investigated, and an ACE inhibitory peptide was identified as Arg-Met-Leu-Gly-GlnThr-Pro-Thr-Lys (Katayama et al., 2003a). The concentration of this nonapeptide necessary to inhibit $50 \%\left(\mathrm{IC}_{50}\right)$ activity of ACE in vitro was 34 $\mu \mathrm{M}$. Peptic hydrolysate of porcine crude myosin also had inhibitory activity with the $50 \%$ inhibitory value of $112 \mu \mathrm{g} / \mathrm{mL}$ (Katayama et al., 2003b). ACE inhibitory peptide had also derived from porcine skeletal muscle myosin and had antihypertensive activity in SHR (Katayama et al., 2007). The peptide was detected as an octapeptide, Val-Lys-Lys-Val-Leu-Gly-Asn-Pro, from $47^{\text {th }}$ to $54^{\text {th }}$ position of myosin light chain. The 50\% inhibitory concentration of this peptide was $28.5 \mu \mathrm{M}$. However, there has been few studies on ACE inhibitory activity and antihypertensive activity derived from meat proteins, especially from Indonesian local animals. In the present study, the ACE inhibitory peptide derived from Kacang goat meat skeletal muscle proteins had been purified and identified. Such activities and substances could be utilized to produce new healthy meat products, which might open up a new market in the meat industry.

\section{MATERIALS AND METHODS}

\section{Samples Collection and Preparation}

Materials used in this study were Kacang goat meat loin (Longissimus dorsi) obtained from central Java area, pepsin (porcine stomach mucosa), trypsin, chymotrypsin obtained from Wako Pure Chemical Industry Ltd., Japan, ACE from rabbit lung obtained from Sigma Chemical Co. St. Louis, USA), Hippuryl-L-Histidyl-LLeucine (HHL) free base obtained from Nacalai Tesque, Kyoto, Japan.

Fifty grams of meat with the addition of 100 $\mathrm{mL}$ water were blended with a Panasonic food processor for $5 \mathrm{~min}$. The meat extract was then homogenized using Polytron PT-MR2000 for 10 $\mathrm{min}$. The meat extract was incubated into shaking water bath Taitec Personal-11 for 30 minutes at $70^{\circ} \mathrm{C}$, and then the extract was cooled with ice.

\section{Hydrolysis protein by pepsin}

Meat extract was adjusted into $\mathrm{pH} 2.0$ with 1 $\mathrm{M} \mathrm{HCl}$. Pepsin (porcine stomach mucosa) was added into the meat extract at the amount of 0.01 g. After 2 hours incubation at $37^{\circ} \mathrm{C}$, the hydrolysate $\mathrm{pH}$ was adjusted to 7.0 with $1 \mathrm{M}$ $\mathrm{NaOH}$, and the hydrolysis by pepsin was terminated by heating at $95^{\circ} \mathrm{C}$ for $10 \mathrm{~min}$, followed by cooling in ice. 


\section{Hydrolysis Protein by Trypsin and Chymotrypsin}

The trypsin and chymotrypsin were added to the peptic hydrolysate at the amount of $0.01 \mathrm{~g}$ each. The peptic hydrolysate was then incubated at $37^{\circ} \mathrm{C}$ for 2 hours. The hydrolysis by trypsin and chymotrypsin was terminated by heating at $95^{\circ} \mathrm{C}$ for $10 \mathrm{~min}$, followed by cooling in ice. Protein hydrolysate was then filtered using $1 \mathrm{~mL}$ syringe set by a filter (Advantec Dismic-25ES, cellulose acetate $0.45 \mu \mathrm{M}$, Toyo Roshi Co., Japan). Filtrate of meat extract was collected for future experiments.

\section{ACE Inhibitory Activity}

The assay of ACE inhibitory activity was determined using the method of Cushman and Cheung (1971). ACE, a dipeptidyl carboxypeptidase (E.C.3.4.15.1), extracted from rabbit lung was obtained from Sigma Chemical Co. Hippuryl-L-histidyl-L-leucine (HHL) obtained from Nacalai Tesque Inc., Kyoto, Japan was used as a synthetic substrate. The ACE inhibitory activity was expressed as the 50\% inhibitory concentration $\left(\mathrm{IC}_{50}\right)$ of the hydrolysate in the assay.

\section{Purification of ACE inhibitory peptide}

Protein hydrolysate was filtered by SEPPAK Plus C18 cartridge (Waters Co., Milford, MA, USA), and eluted by $2 \%$ acetonitrile $\left(\mathrm{CH}_{3} \mathrm{CN}\right)$ and $0.1 \%$ trifluoroacetic acid (TFA) in water, and $65 \% \mathrm{CH}_{3} \mathrm{CN}$ and $0.1 \%$ TFA in water. The purpose of the step was to remove non protein components in the protein hydrolysate. The filtrate was dried up using freeze dryer, and then diluted with water. Filtrat of protein hydrolysate was then applied into several steps of reverse phase high performance liquid chromatography (RP-HPLC) by using a Cosmosil column 5PE-MS, 4.6 X $250 \mathrm{~mm}$ (Nacalai Tesque Co.). First RP-HPLC was eluted by a binary gradient of 0 to $65 \% \mathrm{CH}_{3} \mathrm{CN}$ and $0.1 \%$ TFA in water, with a flow rate of $0.5 \mathrm{~mL} / \mathrm{min}$, and wave length of $215 \mathrm{~nm}$. Fractions were collected every $5 \mathrm{~min}$ and run for $70 \mathrm{~min}$. Second RP-HPLC was eluted by a binary gradient of 10 to $35 \% \mathrm{CH}_{3} \mathrm{CN}$ and $0.1 \%$ TFA in water, with a flow rate of 0.5 $\mathrm{mL} / \mathrm{min}$, and wave length of $215 \mathrm{~nm}$. Fractions were collected every $2.5 \mathrm{~min}$ and run for $50 \mathrm{~min}$. Third RP-HPLC was eluted by a binary gradient of 20 to $25 \% \mathrm{CH}_{3} \mathrm{CN}$ and $0.1 \%$ TFA in water, with a flow rate of $0.5 \mathrm{~mL} / \mathrm{min}$, and wave length of $215 \mathrm{~nm}$. Fractions were collected every $1 \mathrm{~min}$ and run for $30 \mathrm{~min}$. Fourth RP-HPLC was eluted by an isocratic gradient of $15 \% \mathrm{CH}_{3} \mathrm{CN}$ and $0.1 \%$ TFA in water, with a flow rate of $0.5 \mathrm{~mL} / \mathrm{min}$, and wave length of $215 \mathrm{~nm}$. Fractions were collected every $1 \mathrm{~min}$ and run for $20 \mathrm{~min}$. Fifth RP-HPLC was eluted by the same condition of the fourth RP-HPLC. Fraction showing a single peak was collected and tested on the ACE inhibitory activity.

\section{Amino Acid Sequencing}

Fifty $\mu \mathrm{L}$ of fraction showing a single peak was identified the sequence of amino acid by amino acid sequencer in the Laboratory of Shimadzu Technology (Shimadzu Co., Kyoto, Japan).

\section{RESULTS AND DISCUSSIONS}

ACE inhibitory activity of protein hydrolysate of Kacang goat meat had been studied and the sequence of ACE inhibitory peptide of protein hydrolysate had been purified and identified. The protein extracts of Kacang goat meat had no ACE inhibitory activity. However, hydrolysis of protein extracts of Kacang goat meat by the pepsin, trypsin and chymotrypsin showed potential ACE inhibitory activity on their hydrolysate with $\mathrm{IC}_{50}$ of $316 \mu \mathrm{g} / \mathrm{mL}$.

The hydrolysate was then applied to SEPPAK Plus C18 cartridge (Waters Co., Milford, MA, USA) to eliminate the non-protein compounds such as fats and salts. Purified protein was separated using RP-HPLC and eluted with a binary gradient of 0 to $65 \% \mathrm{CH}_{3} \mathrm{CN}$. Fraction No.5 of the first RP-HPLC showed the most ACE inhibitory activity with the ACE inhibitory activity of $65.35 \%$ (Figure 1). Fraction No.5 was then re-separated with the same column and eluted with a binary gradient of 10 to $35 \%$ $\mathrm{CH}_{3} \mathrm{CN}$. Fraction No.5.10 of the second RPHPLC showed the highest ACE inhibitory activity with the ACE inhibitory activity of $73.49 \%$ (Figure 2). Fraction No.5.10 was then reseparated with same column and eluted with a binary gradient of 25 to $30 \% \mathrm{CH}_{3} \mathrm{CN}$. Fraction No.5.10.18 of the third RP-HPLC showed the highest ACE inhibitory activity with the ACE inhibitory activity of $81.33 \%$ (Figure 3 ). Fraction No.5.10.18 was then re-separated with same column and eluted with isocratic flow of $15 \%$ $\mathrm{CH}_{3} \mathrm{CN}$. Fraction No.5.10.18.9 of the fourth RP- 


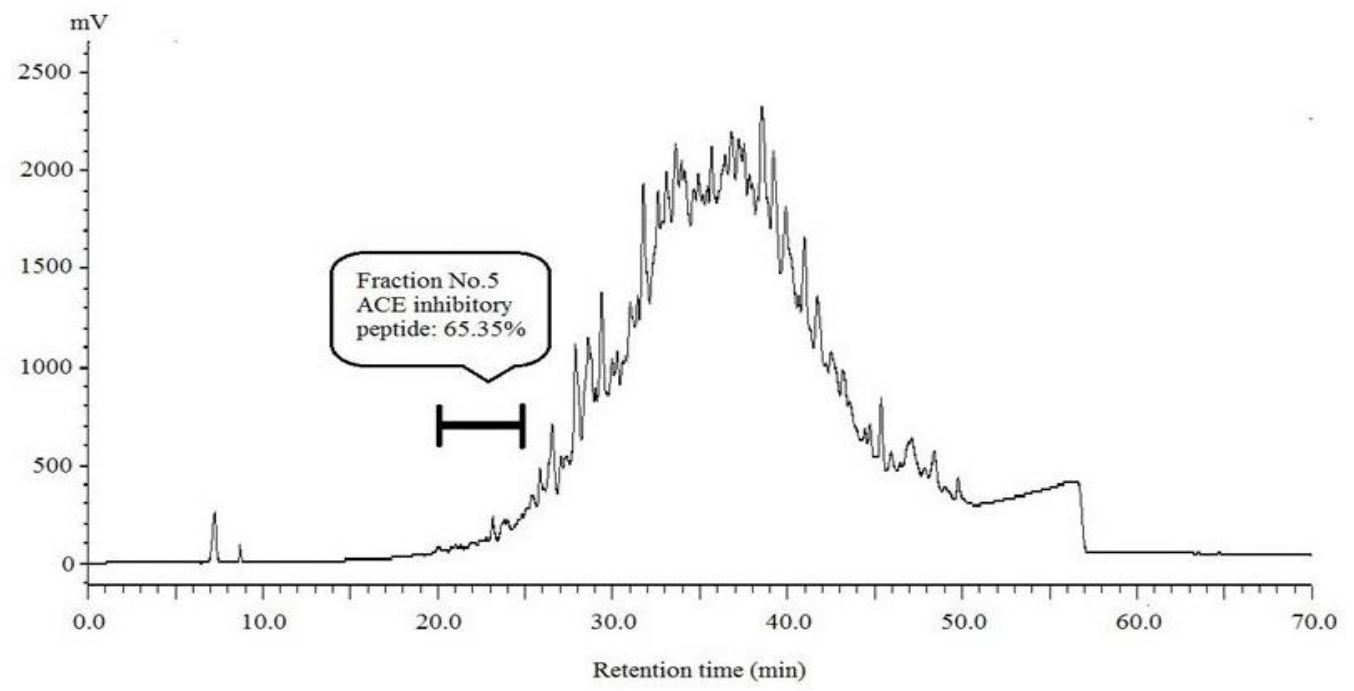

Figure 1. RP-HPLC chromatograms of protein hydrolysates of Kacang Goat meat injected in Cosmosil SPE-MS Column $(4.5 \times 250 \mathrm{~mm})$ (Nacali Tesque). Protein hydrolysate was eluted with a binary gradient of 0 to $65 \% \mathrm{CH}_{3} \mathrm{CN}$ and $1 \%$ TFA in water, with a flow rate of $0.5 \mathrm{~mL} / \mathrm{min}$ and wave length of $215 \mathrm{~nm}$. Fraction No.5 showed highest ACE inhibitory activity of $65.35 \%$.

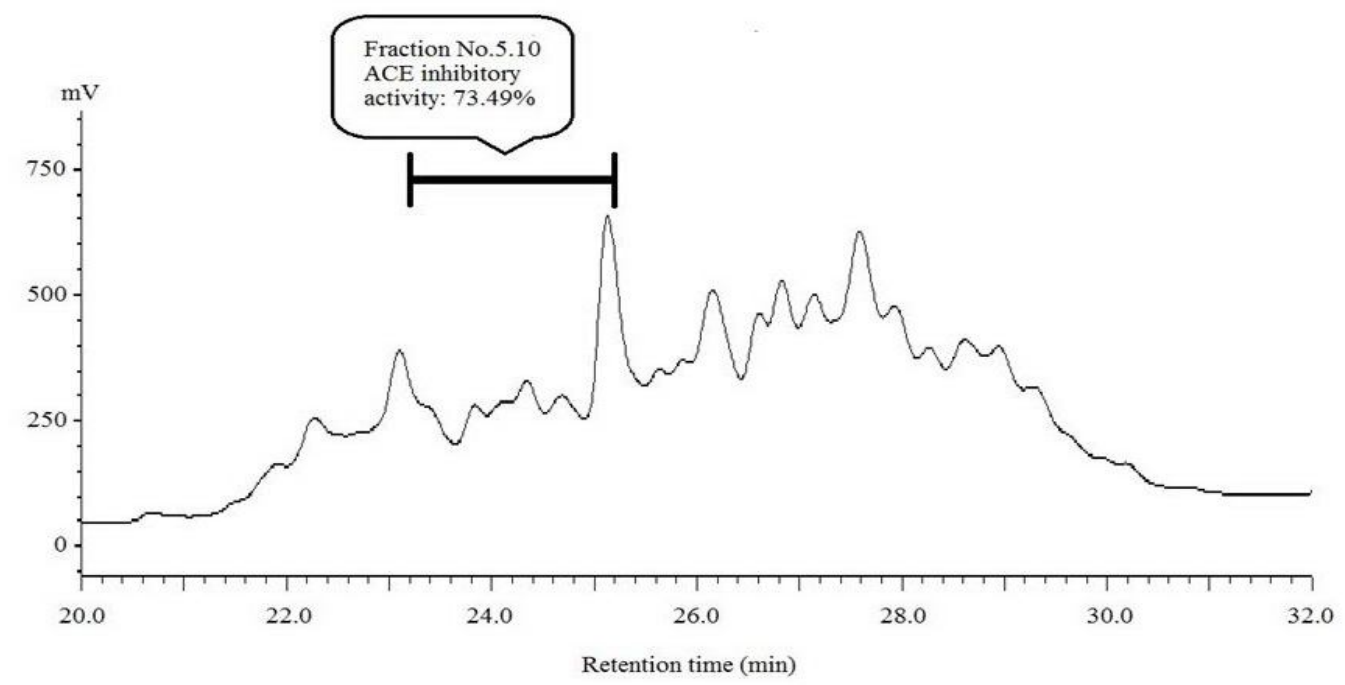

Figure 2. RP-HPLC chromatogram of Fraction No.5 injected in Cosmosil 5PE-MS Column (4.5 x 250 $\mathrm{mm}$ ) (Nacalai Tesque). Fraction No.5 was eluted with a binary gradient of 10 to $35 \% \mathrm{CH}_{3} \mathrm{CN}$ and $1 \%$ TFA in water, with a flow rate of $0.5 \mathrm{~mL} / \mathrm{min}$ and wave length of $215 \mathrm{~nm}$. Fraction No.5.10 showed highest ACE inhibitory activity of $73.49 \%$.

HPLC showed the highest ACE inhibitory activity with the ACE inhibitory activity of $88.67 \%$ (Figure 4). Fraction No.5.10.18.9 of the fourth RP-HPLC was purified again with the same column and eluted with isocratic flow of $15 \%$ $\mathrm{CH}_{3} \mathrm{CN}$. Fraction No.5.10.18.9.9 showing a single peak showed high ACE inhibitory activity with the $\mathrm{IC}_{50}$ of $190 \mu \mathrm{g} / \mathrm{mL}$ (Figure 5).

Analysis of amino acid sequence was performed in Shimadzu Technology (Shimadzu Co., Kyoto, Japan). Fraction No.5.10.18.9.9 showing a single peak produced amino acid sequence of LTEAPLNPKANREK (leu-thr-gluala-pro-leu-asn-pro-lys-ala-arg-asn-glu-lys) and 


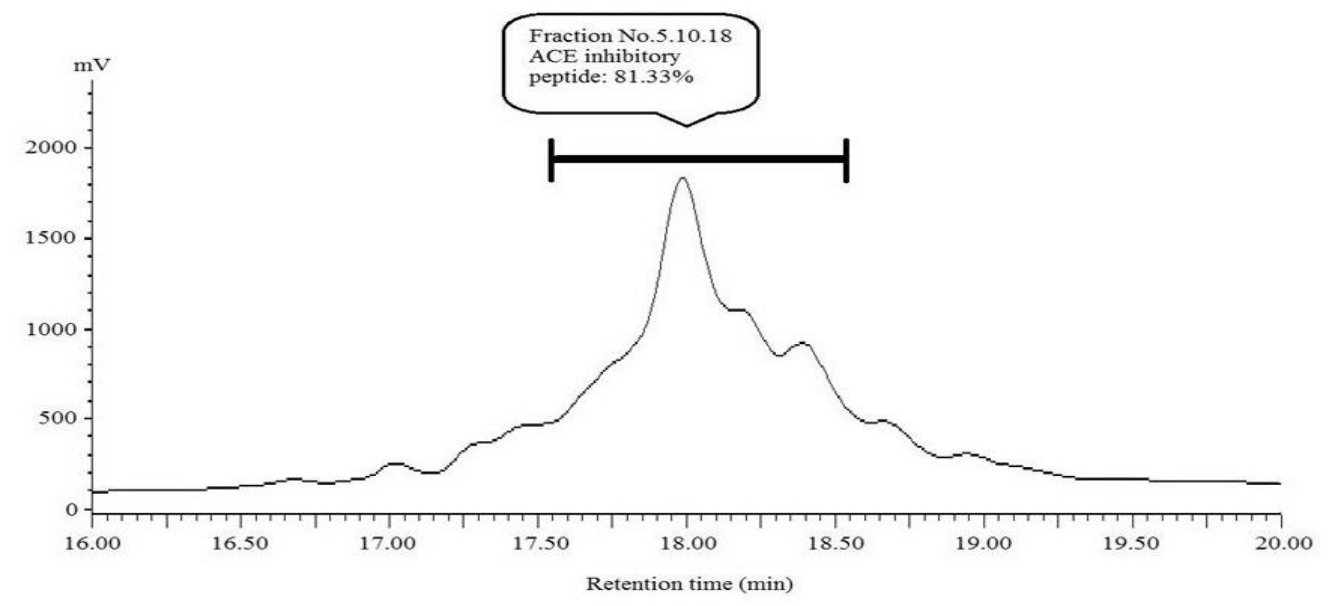

Figure 3. RP-HPLC chromatogram of Fraction No.5.10 injected in Cosmosil 5PE-MS Column (4.5 x $250 \mathrm{~mm}$ ) (Nacalai Tesque). Fraction No.5.10 was eluted with a binary gradient of 20 to $25 \% \mathrm{CH}_{3} \mathrm{CN}$ and $1 \%$ TFA in water, with a flow rate of $0.5 \mathrm{~mL} / \mathrm{min}$ and wave length of $215 \mathrm{~nm}$. Fraction No.5.10.18 showed highest ACE inhibitory activity of $81.33 \%$.

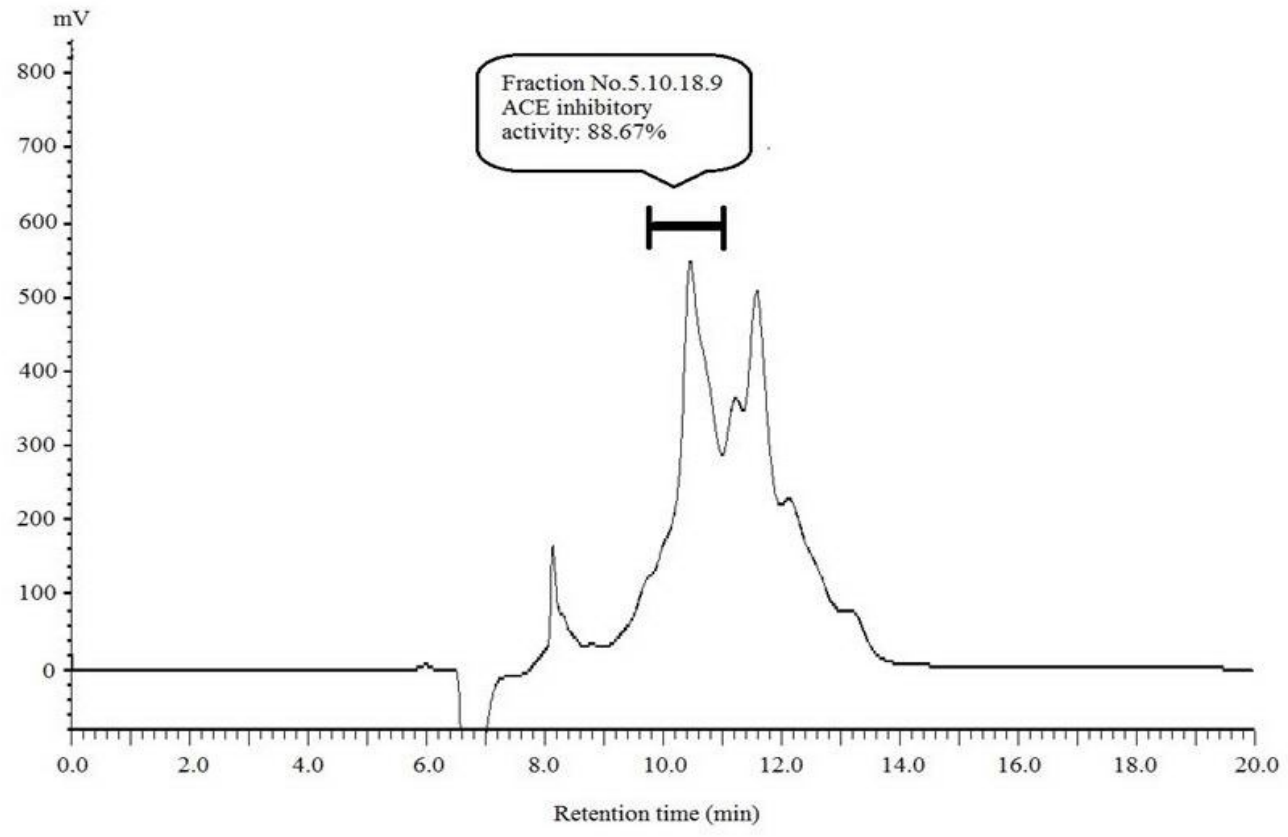

Figure 4. RP-HPLC chromatogram of Fraction No.5.10.18 injected in Cosmosil 5PE-MS Column (4.5 x $250 \mathrm{~mm}$ ) (Nacalai Tesque). Fraction No.5.10.18 was eluted with isocratic flow of $15 \% \mathrm{CH}_{3} \mathrm{CN}$ and $1 \%$ TFA in water, with a flow rate of $0.5 \mathrm{~mL} / \mathrm{min}$ and wave length of $215 \mathrm{~nm}$. Fraction No.5.10.18.9 showed highest ACE inhibitory activity of $88.67 \%$.

had a molecular weight or MW of 1581. Based on the molecular weight of this peptide, it can be expressed as $\mathrm{IC}_{50}$ of $120 \mu \mathrm{M}$. The peptide sequence occurred at the position of $20^{\text {th }}$ to $33^{\text {rd }}$ in the $\beta$-actin from goat meat (Figure 6) (NCBI,
2011). $\beta$-actin is one of the two non muscle cytoskeletal actins. Actins are highly conserved proteins that are involved in cell motility, structure and integrity (Hanukoglu et al., 1983).

The results showed that the sequence of 


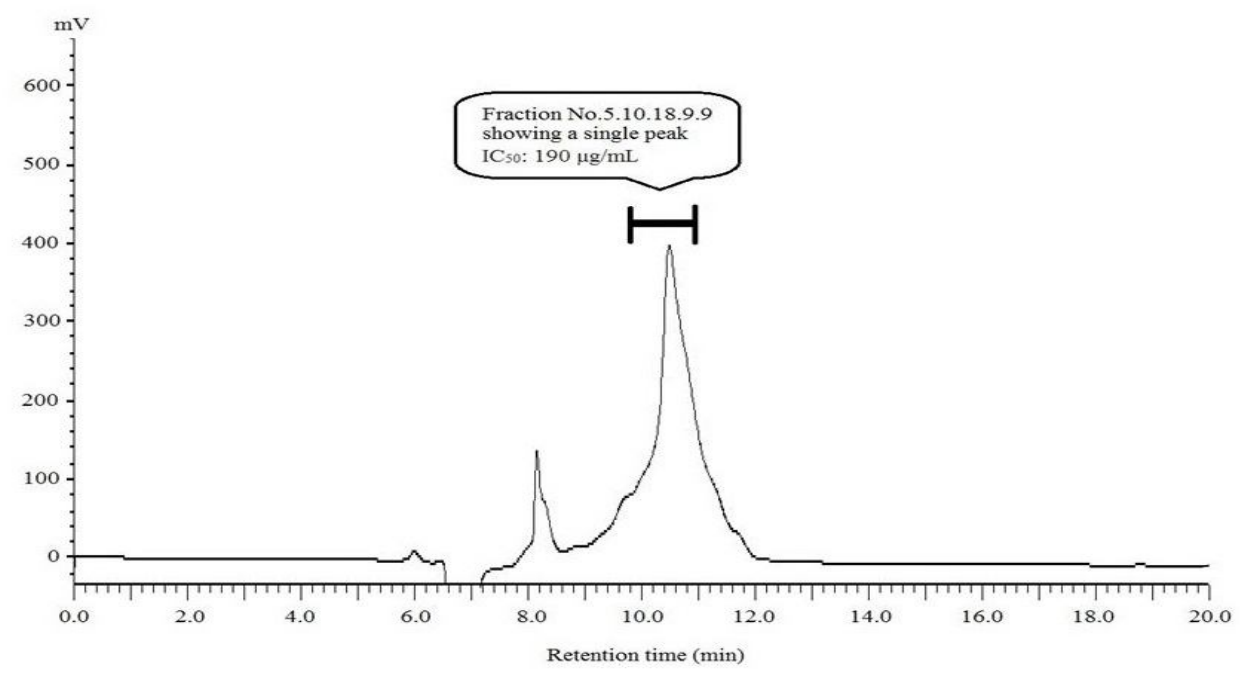

Figure 5. RP-HPLC chromatogram of Fraction No.5.10.18.9 injected in Cosmosil 5PE-MS Column (4.5 x $250 \mathrm{~mm}$ ) (Nacalai Tesque). Fraction No.5.10.18.9 was eluted with isocratic $15 \% \mathrm{CH}_{3} \mathrm{CN}$ and $1 \%$ TFA in water with a flow rate of $0.5 \mathrm{~mL} / \mathrm{min}$ and wave length of $215 \mathrm{~nm}$. Fraction No.5.10.18.9.9 showing a single peak showed $\mathrm{IC}_{50}$ of $190 \mu \mathrm{g} / \mathrm{mL}$, was sequenced in Shimadzu Technology (Kyoto, Japan).

$\begin{array}{rlll}1 & \text { WHHTFYNELR } & \text { VAPEEHPVLL } & \text { TEAPLNPKAN } \\ 31 & \text { REKMTQIMFE } & \text { TFNTPAMYVA } & \text { IQAVLSLYAS } \\ 61 & \text { GRTTGIVMDS } & \text { GDGVTHTVPI } & \text { YEGYALPHAI } \\ 91 & \text { LRLDLAGRDL } & \text { TDYLMKILTE } & \text { RGYSFTTTAE } \\ 121 & \text { REIVRDIKEA } & & \end{array}$

Figure 6. Amino acid sequences of $\beta$-actin of meat goats (Capra hircus). ACE inhibitory peptide of LTEAPLNPKANREK had MW of 1581 , and occurred at the position of $20^{\text {th }}$ to $33^{\text {rd }}$ residues of $\beta$-actin of goat meat protein (Capra hircus) (NCBI, 2011)

amino acids of leu-thr-glu-ala-pro-leu-asn-prolys-ala-arg-asn-glu-lys can be produced from $\beta$ actin of Kacang goat meat protein which was digested by proteases. Chymotrypsin cleaved peptide bound of leu-leu at the position of $19^{\text {th }}$ and $20^{\text {th }}$ residues of goat meat $\beta$-actin (Enenkel and Smillie, 1963 cit. Beck, 1973), and peptide bound of lys-met at the position of $33^{\text {rd }}$ and $34^{\text {th }}$ residues of goat meat $\beta$-actin (Folk and Cole, 1965 cit. Beck, 1973). Besides, peptide bound of lys-met at the position of $33^{\text {rd }}$ and $34^{\text {th }}$ residues of goat meat $\beta$-actin was also cleaved by trypsin (Green and Naurat, 1954 cit. Beck, 1973). Thus, the ACE inhibitory peptides can also be produced from processed meat products. Digestive enzymes such as pepsin, trypsin, and chymotrypsin in the digestive tract can result in ACE inhibitory peptides of muscle protein (Arihara et al., 2001).
Therefore, ACE inhibitory peptides can be produced in the digestive tract from meat consumed. Bioactive components including ACE inhibitory peptides had potential health benefits, and they can be introduced into meat products, thus the value of meat products can be improved. The use of ACE inhibitory peptides from meat protein can produce healthier meat products.

\section{CONCLUSION}

Antihypertensive peptide has been isolated from Kacang goat meat protein hydrolysate. The antihypertensive peptide sequence was leu-thrglu-ala-pro-leu-asn-pro-lys-ala-arg-asn-glu-lys, had a molecular weight (MW) of 1581, and occurred at the position of $20^{\text {th }}$ to $33^{\text {rd }}$ residues of $\beta$-actin of goat meat protein (Capra hircus). The ACE 
inhibitory activity $\left(\mathrm{IC}_{50}\right)$ of the peptide was 190 $\mu \mathrm{g} / \mathrm{mL}$ or $120 \mu \mathrm{M}$.

\section{ACKNOWLEDGMENTS}

The authors would like to express my sincere gratitude to the Directorate of Higher Education of the Ministry of Education and Culture of the Republic of Indonesia, and the Department of Biochemistry and Applied Biosciences, Faculty of Agriculture, University of Miyazaki, Japan.

\section{REFERENCES}

Abubakar, A., T. Saito, H. Kitazawa, Y. Kawai, and T. Itoh. 1998. Structural analysis of new antihypertensive peptides derived from cheese whey protein by protease $\mathrm{K}$ digestion. J. Dairy Sci. 81:3131-3138

Arihara, K., Y. Nakashima, T. Mukai, T. Ishikawa and M. Itoh. 2001. Peptide inhibitors for angiotensin I-converting enzyme from enzymatic hydrolysates of porcine skeletal muscle proteins. Meat Sci. 57:319-24

Ariyoshi, Y. 1993. Angiotensin converting enzyme inhibitors derived from food proteins. Trends in Food Sci. and Tech. 4:139-144

Astawan, M., M. Wahyuni, T. Yasuhara, K. Yamada, T. Tadokoro and A. Maekawa. 1995. Effects of angiotensin I-converting enzyme inhibitory substances derived from Indonesian dried-salted fish on blood pressure of rats. Biosci. Biotech. Biochem. 59(3):425-429

Beck, I.T. 1973. The role of pancreatic enzymes in digestion. Am. J. Clin. Nutr. 26:311-325

Cheung, H.S., F.L. Wang, M.A. Ondetti, E.F. Sabo and D.W. Cushman, 1980. Binding of peptide substrates and inhibitors of angiotensin-converting enzyme. J. Biol. Chem. 255:401-408

Clare, D.A. and H.E.Swaisgood. 2000. Bioactive milk peptides: a prospectus. J. Dairy Sci. 83: 1187-1195

Cushman, D. W., and H.S. Cheung, 1971. Spectrophotometric assay and properties of the angiotensin-converting enzyme of rabbit lung. Biochem. Pharm. 20:1637-1648

Hanukoglu, I., N. Tanese and E. Fuchs. 1983. Complementary DNA sequence of a human cytoplasmic actin. Interspecies divergence of 3' non-coding regions'. J. Mol. Biol. 163(4):673-680
Hata, Y., M. Yamamoto, M. Ohni, K. Nakajima, Y. Nakamura and T. Takano. 1996. A placebocontrolled study of the effect of sour milk on blood pressure in hypertensive subjects. Am. J. Clin. Nutr. 64:767-771

Katayama, K., M. Tomatsu, H. Fuchu, M. Sugiyama, S. Kawahara, K. Yamauchi, Y. Kawamura, and M. Muguruma. 2003a. Purification and characterization of angiotensin I converting enzyme inhibitory peptide derived from porcine troponin $\mathrm{C}$. Anim. Sci. J. 74:53-59

Katayama, K., H. Fuchu, M. Sugiyama, S. Kawahara, K. Yamauchi, Y. Kawamura and M. Muguruma. 2003b. Peptic hydrolysate of porcine crude myosin has many active fractions inhibiting angiotensin I-converting enzyme. Asian-Aust. J. Anim. Sci. 16:13841392

Katayama, K., Jamhari, T. Mori, S. Kawahara, K. Miake, Y. Kodama, M. Sugiyama, Y. Kawamura, T. Nakayama, M. Maruyama and M. Muguruma. 2007. Angiotensin Iconverting enzyme inhibitory peptide derived from porcine skeletal muscle myosin and its antihypertensive activity in spontaneously hypertensive rats. J. Food Sci. 72: S702-S706.

Korhonen, H., A. Pihlanto-Leppala, P. Rantamaki and T. Tupasela, 1998. Impact of processing on bioactive proteins and peptides. Trends in Food Sci. Tech. 9: 307-319

Maruyama, S., H. Mitachi, H. Tanaka, N. Tomizuka and H. Suzuki. 1987. Studies on the active site and antihypertensive activity of angiotensin I-converting enzyme inhibitors derived from casein. Agric. Biol. Chem. 51:1581-1586.

Maruyama, S., S. Miyoshi, T. Kaneko and H. Tanaka. 1989. Angiotensin I-converting enzyme inhibitory activities of synthetic peptides related to the tandem repeated sequence of a maize endosperm protein. Agric. Biol. Chem. 53:1077-1081.

Nakamura, Y., N. Yamamoto, K. Sakai, A. Okubo, S. Yamazaki and T. Takano. 1995. Purifcation and characterization of angiotensin I-converting enzyme inhibitors from sour milk. J. Dairy Sci. 78:777-783

Nakashima, Y., K. Arihara, A. Sasaki, H. Mio, S. Ishikawa and M. Itoh. 2002. Antihypertensive activity of peptides derived from porcine skeletal muscle myosin in spontaneously hypertensive rats. 


\section{J. Food Sci. 67:434-440}

NCBI. 2011. Beta-actin [Capra hircus]. GenBank: AAO49278.1. The National Center for Biotechnology Information. Available on http://www.ncbi.nlm.nih.gov/protein/AAO4 9278.1, Accesed December $21^{\text {th }}, 2011$

Schlimme, E. and H. Meisel. 1995. Bioactive peptides derived from milk proteins. Structural, physiological and analytical aspects. Die Nahrung. 39(1):1-20

Seki, E., K. Osajima, H. Matsufuji, T. Matsui and Y. Osajima, 1995. Val-Tyr, an angiotensin Iconverting enzyme inhibitor from sardines that have resistance to gastrointestinal proteases. Nippon Nogeikagaku Kaishi. 69: 1013-1020

Steijns, J. 1996. Dietary proteins as the source of new health promoting bio-active peptides with special attention to glutamine peptide. Food Technology in Europe. P. 80-84.

Suetsuna K. 1998. Isolation and characterization of angiotensin I-converting enzyme inhibitor dipeptides derived from Allium sativum $L$ (garlic). J. Nutr. Biochem. 9(7):415-419
Yamamoto, N. 1997. Antihypertensive peptides derived from food proteins. Biopolymers. 43:129-134

Yamamoto, N., A. Akino, and T. Takano. 1994. Antihypertensive effect of the peptides derived from casein by an extracellular proteinase from Lactobacillus helveticus CP790. J. Dairy Sci. 77:917-922

Yamamoto, N., M. Maeno and T. Takano. 1999. Purifcation and characterization of an antihypertensive peptide from yogurt-like products fermented by Lactobacillus helveticus CPN4. J. Dairy Sci. 82:13881393

Yokoyama, K., H. Chiba and M. Yoshikawa, 1992. Peptide inhibitors for angiotensin Iconverting enzyme from thermolysin digest of dried bonito. Biosci. Biotech. Biochem. 56:1541-1545

Yoshii, H., N. Tachi, O. Sakamura, H. Takeyama R. Ohba and T. Itani. 1999. Antihypertensive effect of Oligopeptide derived from hen's eggs. Nippon Shokuhin Kagaku Kogaku Kaishi. 46:45-50 